\title{
Morphological variability of the shape of striped red mullet Mullus surmuletus in relation to stock discrimination between the Bay of Biscay and the eastern English Channel
}

\author{
K. Mahe ${ }^{1,{ }^{*}}$, M. C. Villanueva ${ }^{1}$, S. Vaz ${ }^{1}$, F. Coppin ${ }^{1}$, P. Koubbi ${ }^{2}$ and A. Carpentier ${ }^{1}$
}

\footnotetext{
${ }^{1}$ IFREMER, Laboratoire Ressources Halieutiques, 150 quai Gambetta, BP699, 62321 Boulogne-sur-Mer, France 2 UPMC Université Paris VI, UMR 7093, Laboratoire d'Océanographie de Villefranche, 06230 Villefranche-surMer, France
}

*: Corresponding author : Kelig Mahe, tel. +33 321995602 ; email address : Kelig.Mahe@ifremer.fr

\begin{abstract}
:
Truss analysis and length measurements were made on 168 striped red mullet Mullus surmuletus. Multivariate statistical analyses with principal component analysis and partial redundancy analysis ( $p R D A$ ) were used on these measurements to evaluate the influence of maturity, sex and geographical area distribution on body shape. Truss measurements were important to quantify and discriminate changing body shape, presumably due to changing environmental conditions. Sexual dimorphism was not observed and juveniles could be distinguished from adults based on their body shape. More importantly, $M$. surmuletus occurring in different geographical areas could be differentiated using this method. Based on pRDA, a significant difference of head morphological dimensions was observed between populations occurring in the eastern English Channel and those occurring in the Bay of Biscay, suggesting that fish from these areas could represent two subpopulations.
\end{abstract}

Keywords : fish body shape ; head morphology ; morphometric analysis ; stock identification ; Truss model 


\section{Introduction}

Striped red mullet Mullus surmuletus (L. 1758) is an economically important species in the Mediterranean Sea and in the northern Atlantic Ocean, where it is exploited from the Bay of Biscay to the southern North Sea (ICES, 2010). In Atlantic waters there are two main areas where this species is caught, the Bay of Biscay and the Eastern English Channel. This species was initially exploited by the Spanish fleets along the Spanish coast inside the Bay of Biscay. Originally considered as valuable by-catch (Marchal, 2008), the growing exploitation of $M$. surmuletus and a conspicuous increase in landings in the English Channel and the southern North Sea by French, English and Dutch fleets have been observed from the 1990s onwards. This was attributed to an increase in the migratory distribution and abundance of this species in these areas, which is largely heightened by the decline of traditionally targeted species and the trend for sea-water warming (Poulard \& Blanchard, 2005; Marchal, 2008; ICES, 2010). Reports indicate a steady increase in Eastern English Channel landings, now reaching ten times the recorded landing levels of 1990 (Marchal, 2008; Carpentier et al., 2009). Mullus surmuletus is still considered as a non-quota species in the Northeast Atlantic and the evaluation of the level of exploitation only began seven years ago (ICES, 2010).

A stock corresponds to all the individuals that both belong to the same species and live in the same geographical area. The population within a stock is such that breeding is both possible and more likely between any pair within its distribution area than with individuals from other areas. A part or subdivision of a population, often based on geographical consideration, is a subpopulation. Fish stocks may be considered as subpopulations of a particular species of fish, for which intrinsic parameters (growth, recruitment, mortality and fishing mortality) are the only significant factors in determining stock dynamics, while other factors, in particular immigration and emigration, are considered to have limited effect. Information on stock identity and spatial structure provide the basis for understanding fish population dynamics and 
enable reliable resource assessment for fisheries management (Reiss et al., 2009). Each stock may have unique demographic properties and responses or rebuilding capabilities when faced with exploitation. The biological attributes and productivity of the species may be affected if the stock structure considered by fisheries managers is erroneous (Smith et al., 1991).

Stock identification aims to identify these subpopulations and several techniques may be used to this end. For example, tagging experiments, analyses of spatial variation in genetic and morphometric markers, life-history parameters, parasite abundance and contaminants can be used to interpret distribution and relative abundance (Pawson \& Jennings, 1996; Cadrin et al., 2005). Each method offers a unique view of population structure that relates to different definitions of the term "stock" (Begg et al., 1999). Despite a range of difficulties detailed in Jennings et al. (2001), morphological analysis has been useful for fish stock identification. Environmentally induced phenotypic variation provides rapid information on stock or subpopulation identity (Clayton, 1981). This is especially useful when the time at which stock separation occurred is too recent to have allowed considerable accumulation of genetic differentiation among populations.

In the case of M. surmuletus, genetic studies have only been carried out in the Mediterranean Sea (Mamuris et al., 1998a,b, 1999; Apostolidis et al., 2009; Galarza et al., 2009). In the Gulf of Pagasitikos (western Aegean Sea), analyses on three molecular markers revealed panmixia (Apostolidis et al., 2009). In the Mediterranean basin, the Siculo-Tunisian Strait seems to be the transition zone between the Mediterranean's eastern and western populations (Galarza et al., 2009). A sharp genetic division was detected when comparing populations of $M$. surmuletus originating from the Atlantic Ocean or Mediterranean Sea (Galarza et al., 2009).

Otolith microchemistry has also been used to discriminate between subpopulations at different growth stages. However, results are difficult to interpret as trace element deposition can be due to combined effects of physiological, ontogenetic and environmental influences. 
107 As a result, morphological analysis offers a rapid and inexpensive method for population or

108 subpopulation structure identification.

109 To date, very few studies dealing with otolith shape have been conducted on stock structure of

110 M. surmuletus in the north-eastern Atlantic Ocean (Mahé et al., 2005; Benzinou et al., 2013).

111 This region is nevertheless divided into two areas by the International Council for the

112 Exploration of the Sea (ICES) as distinct areas of stock management. The objective of this

113 paper is to evaluate if morphological variations may discriminate populations of $M$.

114 surmuletus sampled in two different ICES areas using geometric morphometric tools.

116 Materials and methods

117 Study sites and sampling

118 Two ICES areas within the northeast Atlantic are considered in this study: the Bay of Biscay

119 and the Eastern English Channel (Fig. 1) where annual research surveys are conducted to

120 evaluate commercial fish abundance. The Bay of Biscay (ICES areas VIIIa and b) has a large

121 continental shelf with water depth reaching down to $200 \mathrm{~m}$. Average annual water

122 temperature increases from the northern part $\left(11.2^{\circ} \mathrm{C}\right.$ at $\left.48{ }^{\circ} \mathrm{N}\right)$ to the southern part $\left(15.6^{\circ} \mathrm{C}\right.$

123 at $36^{\circ} \mathrm{N}$ ) of the North-eastern Atlantic region. The substrate varies from a muddy bottom

124 along the shelf break to rocky or sandy substrates along the inner shelf (depth $<100 \mathrm{~m})$. The

125 eastern English Channel (ICES area VIId) is an epicontinental area characterized by a strong

126 tidal regime. Water depth declines from $70 \mathrm{~m}$ off Cherbourg to $40 \mathrm{~m}$ in the centre of the

127 Dover Strait. Seabed sediment types vary from west to east and are strongly influenced by the

128 tidal currents. Pebbly bottoms occur in open waters off Cherbourg followed by a progression

129 towards gravel, then coarse to fine sands toward the eastern coasts and even mud in the

130 sheltered estuarine bays. Pebbles and rocks are found again in the narrows of the Dover strait 
131 where tidal currents are very strong. Average annual water temperature is $13.3{ }^{\circ} \mathrm{C}$ (Carpentier

132 et al., 2009).

133 Mullus surmuletus were sampled during two annual scientific surveys using GOV bottom

134 trawls (very high vertical opening, square mesh size in the cod end: $10 \mathrm{~mm}$ side). In the Bay 135 of Biscay, fish were collected during the Western Europe fisheries resources evaluation

136 (EValuation des resources Halieutiques de l'Ouest de l'Europe, EVHOE) survey in October-

137 November 2003 onboard the research vessel (RV) "Thalassa". In the Eastern English

138 Channel, samples were collected during the Channel Ground Fish Survey (CGFS) during

139 October-November 2002 and 2003 onboard the RV "Gwen-Drez."

140 A total of 168 individuals were sampled: 111 in the Eastern English Channel and 57 in the

141 Bay of Biscay. All fresh M. surmuletus were measured for total length $\left(L_{\mathrm{T}} \pm 1 \mathrm{~mm}\right)$, mass

$142(\mathrm{~W} \pm 1 \mathrm{~g})$ and sexed. The total length ranged from 82 to $345 \mathrm{~mm}$ for individuals collected in the

143 Bay of Biscay, and from 90 to $372 \mathrm{~mm}$ for those sampled in the Eastern English Channel

144 (Table I). The total mass (W) varied from 10 to $625 \mathrm{~g}$ and 6 to $692 \mathrm{~g}$ for individuals collected

145 in the Bay of Biscay and in the eastern English Channel respectively. Macroscopic

146 observation of gonads based on scale proposed by Mahé et al. (2005) was used to determine

147 individual sex and maturity. In the Bay of Biscay, this species principally occurs along the

148 northern area close to the Loire estuary (Fig. 1) while in the eastern English Channel this

149 species is mainly found in the Dover Strait and Bay of Seine areas.

150 Image analyses

151 Each individual was photographed using a digital camera. A calibrated image of each

152 individual (positioned head on the left and deployed fins) was obtained using the Optimas 6

153 software (Anonymous, 1996). This software was used to enable identification of homologous

154 points or landmarks and to calculate distances between these points. 
155 The Truss network method (Strauss \& Bookstein, 1982) was used and 10 landmark points

156 were identified on the outline of the body (head: 1-2; dorsal fin: 3; adipose fin: 4-5; caudal 157 fin: 6-7; anal fin: 8-9; pelvic fin: 10; see Fig. 2). Three categories of clearly defined

158 landmarks are identified: Type 1 is a mathematical point such as a local juxtaposition of two

159 different tissues (3-7, 9-10), Type 2 is a point marking the geometrical structure of the

160 individual (1-2) and Type 3 is based on another structure or point (8) (Slice et al., 1996).

161 Consequently from these 10 selected points, 21 segments (or distances) are established and 162 measured with a precision of $0.001 \mathrm{~mm}$ (Fig. 2).

163 Data processing

164 To investigate possible variations of fish shape according to five explanatory variables

165 (geographical area, maturity, body length, body mass and sex), the normal distribution of 166 segments was checked using kurtosis and skewness coefficients. Principal component 167 analysis (PCA) was applied to truss size variables to outline groups of samples and to identify 168 influential variables. Principal components were extracted from the covariance matrix. 169 Allometric analyses and PCAs showed that these distances are related to the overall length of 170 individuals. Partial redundancy analysis (pRDA) was primarily carried out using CANOCO 171 by extracting the variance explained by total length used as a covariate (ter Braak \& Smilauer, 172 2002). In the resulting partial analysis, it is possible to test and extract the relevant 173 explanatory variables related to the variation in fish morphology independently from the

174 individual total length. The pRDA was used in combination with Monte Carlo permutation 175 tests to explore the multi-linear relationships between morphometric data and un-biased 176 geographical and sex descriptors. 


\section{Results}

179 Principal component analysis of truss variables reveals that the first principal component

180 accounts for $96.7 \%$ of the total variance. There is an unbiased correlation between segments, 181 body size and body mass which is directly related to individual size (Fig. 3).

182 The strong correlation with the fish size potentially masks morphological differences between

183 sexes and geographical sectors. A pRDA was therefore carried out (Fig. 4) to remove the 184 observed effect of fish size. No significant morphological differences are observed from inter185 annual (2002-2003) individual samples analysed in the Eastern English Channel (Fig. 4). 186 Likewise, the pRDA does not reveal any significant sexual dimorphism $(\mathrm{p}=0.134)$. However, 187 this analysis clearly separates individuals from the Bay of Biscay (EVHOE) from those of the

188 Eastern English Channel (CGFS). Segments D1-2, D1-3, D1-10, D2-3 and D4-5 are 189 associated to the EVHOE survey (Fig. 2). All these segments are on the head, except for D4-5 190 (adipose fin).

191 The individuals collected from the Bay of Biscay appear to have a more ventrally positioned

192 mouth than those captured in the Eastern English Channel and this significant difference 193 indicates two stock components (Fig. 5). Shape divergences are also observed between 194 juvenile (smaller bodied) and adult (larger bodied) stages collected within the Eastern English 195 Channel. Multivariate analyses were also performed on body mass data, but results show that 196 this factor does not discriminate between populations of M. surmuletus from different areas.

198 Discussion

199 The truss network analysis identifies two distinct subpopulations of M. surmuletus from the 200 Bay of Biscay and the Eastern English Channel. This study demonstrates that populations in 201 the two areas can be discriminated based on morphology, even when fish size effect is 202 removed. These results corroborate those obtained from a study of otolith shape (Benzinou $e t$ 
al., 2013). Little morphological variability was observed between sexes. This weak sexual

204 dimorphism may be attributed to the sampling period, which did not coincide with spawning period. All samples were collected in October and November, whereas the reproductive season of M. surmuletus occurs between May and September in the North-Eastern Atlantic (N'Da \& Deniel, 1993).

In general, morphological variability may result from genetic variation (Griffiths et al., 2010) or phenotypic plasticity (Schlichting \& Pigliucci, 1998; Moe et al., 2004) induced by different environmental conditions prevailing in each geographic area (Corti et al., 1996; Clabaut et al., 2007). In particular, morphological variability may reflect local food availability and feeding conditions prevailing in each area; a relatively low rate of egg and larval transportation or 213 migration for the adult fish; limited swimming performance or geographical constraints 214 imposed on the subpopulations; and last but not least, the differential impact of fisheries (i.e. different fishing patterns), which might determine different selection effects (for example, smaller lengths at maturity).

217 External shape and internal anatomical development are affected by the environmental 218 conditions of growth (e.g., climate, food limitation, interaction, exploitation, other stressors), 219 especially during juvenile (developmental) stages (Loy et al., 2000; Moe et al., 2004). Food availability has been observed in other studies as a factor affecting fish morphology and behaviour (Moe et al., 2004; Borcherding \& Magnhagen, 2008). Consumption of more energy rich prey may also contribute to change in body shape development.

Mullus surmuletus exhibits an opportunistic and benthivorous feeding habit on sandy and 224 rocky bottoms (Lombarte \& Aguirre, 1997; Mazzola et al., 1999). In our study, M. surmuletus 225 from the Bay of Biscay were found mainly over sandy and rocky bottoms. In the eastern 226 English Channel, the habitats of $M$. surmuletus also include rocky and sandy substrates but 227 are dominated by coarse sands, gravels and pebbles. Species that can occupy several habitat 
(substrate) types may develop a wider dietary breadth and morphological variation, which may have resulted in head shape modifications of $M$. surmuletus in the eastern English Channel.

231 Previous studies have investigated the diet of $M$. surmuletus. In these studies, juveniles consume large quantities of polychaetes and other prey such as copepods, harpacticoids, amphipods and Tanaidacea (N'Da, 1992; Labropoulou et al., 1997; Mazzola et al., 1999;

234 Bautista-Vega et al., 2008). Adults fed mainly on crustaceans (shrimps and crabs) and other benthic organisms such as polychaetes, molluscs and echinoderms, as well as on small forage fish (Badalamenti \& Riggio, 1989; Golani \& Galil, 1991; N'Da, 1992; Mazzola et al., 1999; Bautista-Vega et al., 2008). The observed ontogenetic changes in feeding habits may explain 238 shape divergences between juvenile and adult of $M$. surmuletus.

239 The truss network has been a useful tool to discriminate subpopulations of $M$. surmuletus 240 from two different ecosystems based on fish shape and directly comparable with the results 241 obtained by the study of otolith shape (Benzinou et al., 2013). Similar patterns of 242 differentiation have been observed for others species, based on morphological, otolith and 243 genetic characters (Cadrin et al., 2005; Kristoffersen \& Magoulas, 2008). Morphological 244 variation may be greater than the differentiation found at the genetic level (Stepien et al., 245 1994). These morphological differences between habitats, could, to some extent, reflect 246 phenotypic plasticity (Mamuris et al., 1998b; Uiblein et al., 1998). In this study, the 247 significant morphometric divergence observed could indicate isolation between these two 248 populations. Fage (1909) distinguished a southern and a northern form of M. surmuletus 249 based mainly on head shape. Moreover, the strong increase in numbers of individuals of $M$. 250 surmuletus reported in landings from the English Channel and the southern North Sea since 251 the 1990s has also been observed in the northern North Sea (Beare et al., 2005; Engelhard et 252 al., 2011). Beare et al. (2005) observed that the increased abundance of M. surmuletus in the 
253

northern North Sea could be due to a winter migration of a larger resident population in the southern North Sea, when water temperatures in the northern part of the North Sea are higher than in the southern part. There is a positive relationship between the abundance of this species and water temperature (Cushing, 1982; Vaz et al., 2004; Beare et al., 2005). Hence, the increasing presence of $M$. surmuletus in northern parts of its distribution range could be in response to warming climate (Engelhard et al., 2011). Recently, Mahé et al. (2013) showed that growth rate of M. surmuletus in the eastern English Channel and southern North Sea is higher than those observed in southern areas. Feeding behaviour is a well-known factor that influences head morphology (Hyndes et al., 1997; Delariva \& Agostinho, 2001; Palma \& Andrade, 2002; Silva, 2003; Janhuen et al., 2009) and an organism's (somatic) growth (Loy et $a l ., 2000)$. Thus, fish trophic ecology might be one of the principal explanatory factors for morphological divergences observed in the current study. Unfortunately, the effects of trophic ecology on variation of the morphology of M. surmuletus cannot be quantitatively accounted for because food and feeding patterns of M. surmuletus have not been considered on samples collected for this study. Spline values observed on head dimensions of M. surmuletus are likely to be related to trophic differences and exposure to various environmental conditions in different habitats during important developmental periods. Genetic, otolith and trophic characterisation studies are future research programs that can be combined to this method to achieve a more reliable determination of stock structure, which is critically relevant to its successful management.

\section{Acknowledgements}

We would like to express our gratitude to all people involved in the collection of $M$. surmuletus required in this study. Thanks are expressed to the crew of the RV «Thalassa » and the RV «Gwen Drez » during the EVHOE and CGFS surveys. This work is a part of the 
278 "Le rouget barbet de roche Mullus surmuletus (L. 1758) en Manche orientale et mer du Nord 279 " regional project. We acknowledge the help of Willie McCurdy for improvement of the 280 language. We are grateful for the constructive comments provided by the reviewers and the 281 associated editors.

\section{References}

284 Anonymous (1996). OPTIMAS 6. User guide and technical reference, 8th eds. Silver Spring, 285 Maryland: Media Cybernetics.

Apostolidis, A. P., Moutou, K. A., Stamatis, C. \& Mamuris, Z. (2009). Genetic structure of three marine fish from the Gulf of Pagasitikos (Greece) based on allozymes, RAPD, and mtDNA RFLP markers. Biologia 64, 1005-1010.

289 Badalamenti, F. \& Riggio, S. (1989). Polychaetes in the gut contents of Mullus surmuletus L. 290 (Pisces, Mullidae) in the Bay of Palermo. Oebalia 15, 79-87.doi:10.1046/j.14390426.1999.00135.x

Bautista-Vega, A. A., Letourneur, Y., Harmelin-Vivien, M. \& Salen-Picard, C. (2008). Difference in diet and size-related trophic level in two sympatric fish species, the red mullets 294 Mullus barbatus and Mullus surmuletus, in the Gulf of Lions (north-west Mediterranean Sea). Journal of Fish Biology 73, 2402-2420.doi:10.1111/j.1095-8649.2008.02093.x

Beare, D.J., Burns, F., Peach, K. \& Reid, D. G. (2005). Red mullet migration into the northern

297 North Sea during late winter. Journal of Sea Research 53, 205298 212.doi:10.1016/j.seares.2004.06.003

299 Begg, G. A., Friedland, K. D. \& Pearce, J. B. (1999). Stock Identification : Its role in stock 300 assessment and fisheries management. Fisheries Research Special Issue 43, 1-252.

301 Benzinou, A., Carbini, S., Nasreddine, K., Elleboode, R. \& Mahé, K. (2013). Discriminating stocks of striped red mullet (Mullus surmuletus) in the Northwest European seas using three 
automatic shape classification methods. Fisheries Research 143, 153-160. doi:10.1016/j.fishres.2013.01.015

305 Borcherding, J. \& Magnhagen, C. (2008). Food abundance affects both morphology and 306 behaviour of juvenile perch. Ecology of Freshwater Fish 17, 207-218.doi:10.1111/j.1600$307 \quad 0633.2007 .00272 . x$

308 Cadrin, S. X., Friedland, K. D. \& Waldman, J. R. (2005). Stock identification methods: 309 applications in fishery science, Academic Press.

310 Carpentier, A., Martin, C. S. \& Vaz, S. (2009). Channel Habitat Atlas for marine Resource 311 Management (CHARM phase II), INTERREG 3a Programme, IFREMER, Boulogne-sur-mer.

312 Clabaut, C., Bunje, P. M. E., Salzburger, W. \& Meyer, A. (2007). Geometric morphometric 313 analyses provide evidence for the adaptive character of the Tanganyikan cichlid dish 314 radiations. Evolution 61, 560-578.

315 Clayton, J. W. (1981). The stock concept and the uncoupling of organismal and molecular 316 evolution. Canadian Journal of Fisheries and Aquatic Sciences 38, 1515317 1522.doi:10.1139/f81-204

318 Corti, M., Loy, A. \& Cataudella, S. (1996). Form changes in the sea bass, Dicentrarchus 319 labrax (Moronidae Teleostei), after acclimation to freshwater: An analysis using shape 320 coordinates. Environmental Biology of Fishes 47, 165-175.

321 Cushing, D. H. (1982). Climate and Fisheries. London: Academic Press.

322 Delariva, R. L. \& Agostinho, A. A. (2001). Relationship between morphology and diets of six 323 neotropical loricariids. Journal of Fish Biology 58, 832-847.doi:10.1111/j.1095324 8649.2001.tb00534.x

325 Engelhard, G. H., Ellis, J. R., Payne, M. R., ter Hofstede, R., \& Pinnegar, J. K. (2011). 326 Ecotypes as a concept for exploring responses to climate change in fish assemblages. ICES 327 Journal of Marine Science 68, 580-591.doi:10.1093/icesjms/fsq183 
328 Fage, L. (1909).Etude de la variation chez le rouget (Mullus barbatus L.M. surmuletus L.).

329 Archives de Zoologie Expérimentale et Générale 5, 389-445.

330 Galarza, J. A., Turner, G. F., Macpherson, E. \& Rico, C. (2009). Patterns of genetic

331 differentiation between two co-occurring demersal species: the red mullet (Mullus barbatus)

332 and the striped red mullet (Mullus surmuletus). Canadian Journal of Fisheries and Aquatic

333 Sciences 66, 1478-1490.doi:10.1139/F09-098

334 Golani, D. \& Galil, B. (1991). Trophic relationships of colonizing and indigenous goatfish

335 (Mullidae) in the Eastern Mediterranean with special emphasis on decapod crustaceans.

336 Hydrobiologia 218, 27-33.doi:10.1007/BF00006415

337 Griffiths, A. M., Machado-Schiaffino, G., Dillane, E., Coughlan, J., Horreo, J. L., Bowkett, A.

338 E., Minting, P., Toms, S., Roche, W., Gargan, P., McGinnity, P., Cross, T., Bright, D.,

339 Garcia-Vazquez, E. \& Stevens, J. R. (2010). Genetic stock identification of Atlantic salmon

340 (Salmo salar) populations in the southern part of the European range. BMC Genetics 11, 1-31.

341 Hyndes, G. A., Platell, M. E. \& Potter, I. C. (1997). Relationships between diet and body size,

342 mouth morphology, habitat and movement of six sillaginid species in coastal waters:

343 implications for resource partitioning. Marine Biology 128, 585-598.

344 ICES. (2010). Report of the Working Group on Assessment of New MoU Species 345 (WGNEW). ICES CM 2010/ACOM: 21.

346 Janhunen, M., Peuhkuri, N. \& Piironen, J. (2009). Morphological variability among three 347 geographically distinct Arctic charr (Salvelinus alpinus L.) populations reared in a common 348 hatchery environment. Ecology of Freshwater Fish 18, 106-116.doi:10.1111/j.1600$349 \quad 0633.2008 .00329 . x$

350 Jennings, S., Kaiser, M. J. \& Reynolds., J. D. (2001). Marine Fisheries Ecology. Blackwell 351 Science, Oxford, England. 
352 Kristoffersen, J. B. \& Magoulas, A. (2008). Population structure of anchovy Engraulis 353 encrasicolus L. in the Mediterranean Sea inferred from multiple methods. Fisheries Research 354 91, 187-195. doi:10.1016/j.fishres.2007.11.024.

355 Labropoulou, M., Machias, A., Tsimenides, N. \& Eleftheriou, A. (1997). Feeding habits and 356 ontogenetic shift of the striped red mullet, Mullus surmuletus Linnaeus, 1758. Fisheries $357 \quad$ Research 31, 257-267.doi: 10.1016/S0165-7836(97)00017-9

358 Lombarte, A. \& Aguirre, H. (1997). Quantitative differences in the chemoreceptor systems in 359 the barbels of two species of Mullidae (Mullus surmuletus and M. barbatus) with different 360 bottom habitats. Marine Ecology Progress Series 150, 57-64.doi:10.3354/meps150057

361 Loy, A., Busilacchi, S., Costa, C., Ferlin, L. \& Cataudella, S. (2000). Comparing geometric 362 morphometrics and outline fitting methods to monitor fish shape variability of $D$. puntazzo

363 (Teleostea: Sparidae). Aquaculture Research 21, 271-283.doi :10.1016/S0144364 8609(99)00035-7

365 Mahé, K., Destombes, A., Coppin, F., Koubbi, P., Vaz, S., Le Roy, D. \& Carpentier, A. 366 (2005). Le rouget barbet de roche Mullus surmuletus (L. 1758) en Manche orientale et mer $367 d u$ Nord. Rapport de Contrat IFREMER/CRPMEM Nord-Pas-de-Calais, IFREMER, 368 Boulogne-sur-mer.

369 Mahé, K., Coppin, F., Vaz, S., \& Carpentier, A. (2013). Striped red mullet (Mullus 370 surmuletus, Linnaeus, 1758) in the eastern English Channel and southern North Sea: growth 371 and reproductive biology. Journal of Applied Ichthyology 29, 1067-1072.doi: 372 10.1111/jai.12266

373 Mamuris, Z., Apostolidis, A. P. \& Triantaphyllidis, C. (1998a). Genetic protein variation in 374 red mullet (Mullus barbatus) and striped red mullet (M. surmuletus) populations from the 375 Mediterranean Sea. Marine Biology 130, 353-360. 
376 Mamuris, Z., Apostolidis, A. P., Panagiotaki, P., Theodorou, A. J. \& Triantaphyllidis, C. 377 (1998b). Morphological variation between red mullet populations in Greece. Journal of Fish 378 Biology 52, 107-117.

379 Mamuris, Z., Stamatis C., Triantaphyllidis, C. (1999). Intraspecific genetic variation of 380 striped red mullet (Mullus surmuletus, L.) in the Mediterranean Sea assessed by allozyme and 381 Random Amplified Polymorphic DNA (RAPD) analysis. Heredity 83, 30-38.

382 Marchal, P. (2008). A comparative analysis of métiers and catch profiles for some French 383 demersal and pelagic fleets. ICES Journal of Marine Science 65, 674384 686.doi:10.1093/icesjms/fsn044

385 Mazzola, A., Lopiano, L., La Rosa, T. \& Sara, G. (1999). Diel feeding habits of juveniles of 386 Mullus surmuletus (Linneo, 1758) in the lagoon of the Stagnone di Marsala (western Sicily, 387 Italy). Journal of Applied Ichthyology 15, 143-148.doi: 10.1046/j.1439-0426.1999.00135.x 388 Moe, B., Brunvoll, S., Mork, D., Brobakk, T. E. \& Bech, C. (2004). Developmental plasticity 389 of physiology and morphology in diet-restricted European shag nestlings (Phalacrocorax 390 aristotelis). Journal of Experimental Biology 207, 4067-4076.doi:10.1242/jeb.01226

391 N'Da, K. \& Deniel, C. (1993). Sexual cycle and seasonal changes in the ovary of the red 392 mullet Mullus surmuletus Linné 1758, from the southern coast of Brittany. Journal of Fish 393 Biology 43, 224-244.doi:10.1111/j.1095-8649.1993.tb00425.x

394 Palma, J. \& Andrade, J. P. (2002). Morphological study of Diplodus sargus, Diplodus 395 puntazzo, and Lithognathus mormyrus (Sparidae) in the Eastern Atlantic and Mediterranean 396 Sea. Fisheries Research 57, 1-8.

397 Pawson, M. G. \& Jennings, S. (1996). A critique of methods for stock identification in marine 398 capture fisheries. Fisheries Research 25, 3-4. 
Poulard, J. C. \& Blanchard, F. (2005). The impact of climate change on the fish community

400 structure of the eastern continental shelf of the Bay of Biscay. ICES Journal of Marine

$401 \quad$ Science 62, 1436-1443.doi:10.1016/j.icesjms.2005.04.017

402 Reiss, H., Hoarau, G., Dickey-Collas, M. \& Wolff, W. J. (2009). Genetic population structure 403 of marine fish: mismatch between biological and fisheries management units. Fish and 404 Fisheries 10, 361-395.doi:10.1111/j.1467-2979.2008.00324.x

405 Schlichting, C. D. \& Pigliucci, M. (1998). Phenotypic evolution: A reaction norm perspective. 406 Sunderland: Sinauer.

407 Silva, A. (2003). Morphometric variation among sardine (Sardina pilchardus) populations 408 from the northeastern Atlantic and the western Mediterranean. ICES Journal of Marine 409 Science 60, 1352-1360.doi:10.1016/S1054e3139(03)00141-3

410 Slice, D. E., Bookstein, F. L., Marcus, F. \& Rohlf, F. J. (1996). A glossary for geometric 411 morphometrics. In Advances in morphometrics (Marcus, L. F., Corti, M., Loy, A., Naylor, G. 412 J. P. and Slice, D. E. E., eds), pp. 531-551. Springer Publishing.

413 Smith, P. J., Francis, R. I. C. C. \& McVeagh, M. (1991). Loss of genetic diversity due to 414 fishing pressure. Fisheries Research 10, 309-316.doi:10.1016/0165-7836(91)90082-Q

415 Stepien, C. A., Randall, J. E. \& Rosenblatt, R. H. (1994). Genetic and morphological 416 divergence of a circumtropical complex of goatfishes: Mulloidichthys vanicolensis, $M$. 417 dentatus, and M.martinicus. Pacific Science 48, 44-56.

418 Strauss, R. E. \& Bookstein, F. L. (1982). The TRUSS : body form reconstructions in 419 morphometrics. Systematic Zoology 31, 113-135.

420 ter Braak, C. J. F. ter. \& Smilauer, P. (2002). CANOCO Reference Manual and CanoDraw for 421 Windows User's Guide: Software for Canonical Community Ordination, Ithaca, New-York.

422 Uiblein, F. (2007). Goatfishes (Mullidae) as indicators in tropical and temperate coastal 423 habitat monitoring and management. Marine Biology Research 3, 275-288. 
424 Uiblein, F., Köhler, C. \& Tian, M. C. (1998). Quantitative examination of morphological 425 variability among goatfishes of the genus Upeneus from the Malayan Province (Pisces: 426 Perciformes: Mullidae). Senckenbergiana Maritime 28, 123-132.

427 Vaz, S., Carpentier, A. \& Coppin, F. (2004). Eastern English Channel fish community from 4281988 to 2003 and its relation to the environment. ICES CM 2004/K:40.

432 Figure 1: Map showing location of sampling areas with ICES divisions (IVc, VIId, VIIe, 433 VIIIa \& VIIIb). 


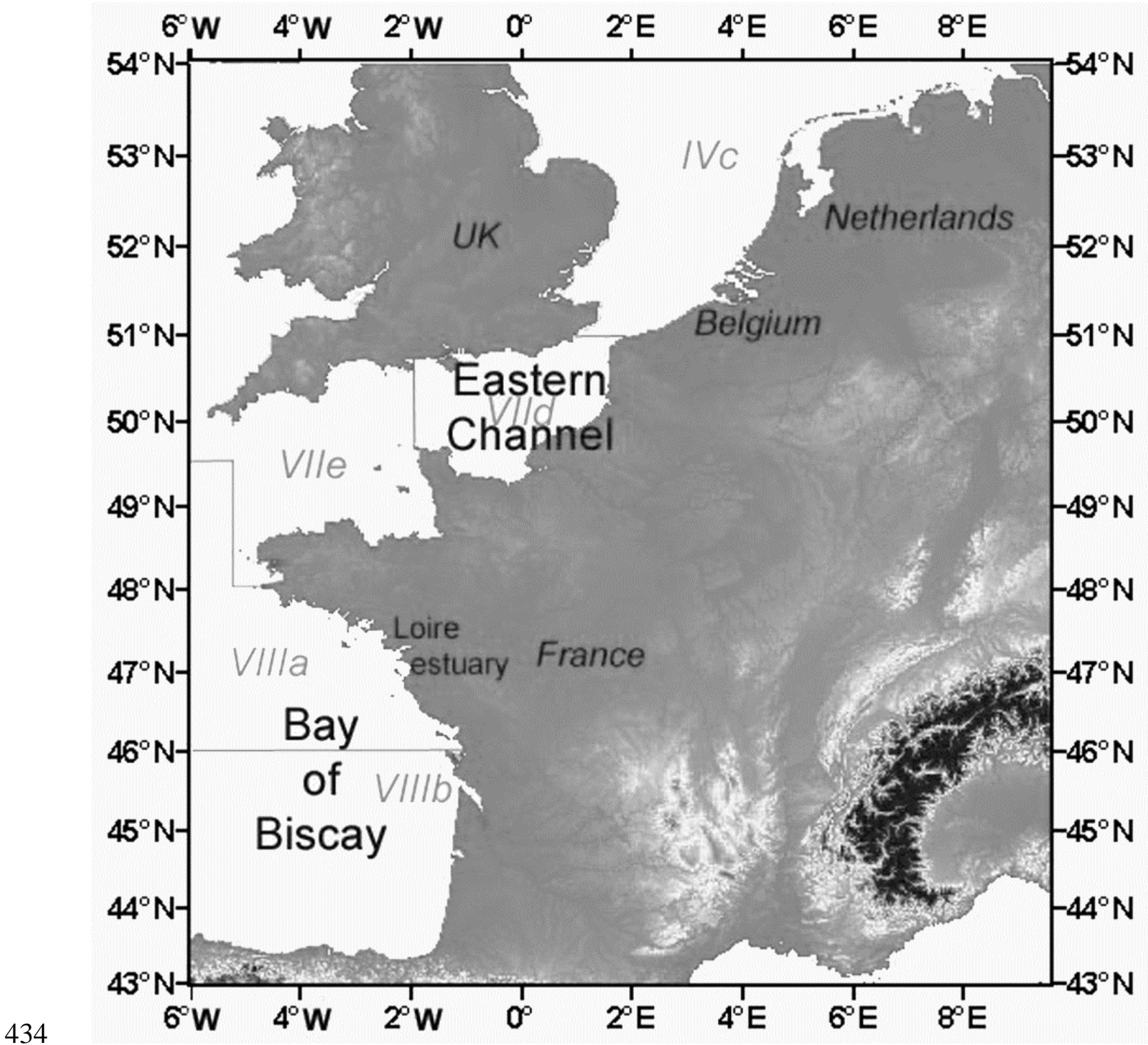

435

436

437

438

439

440

441

442 
443 Figure 2 : The 10 homologous landmarks used to calculate the truss networks (lines) on $M$. 444 surmuletus.

445




460 Figure 3: Main results of the principal components analysis. Open squares and circles 461 represent individual fish specimens analyzed from the Eastern English Channel and the Bay 462 of Biscay, respectively.




475 Figure 4: Main results of the Redundancy Partial Analyses. Squares (black: 2002 \& open:

476 2003) and circles represent individual fish specimens analyzed from the Eastern English

477 Channel and the Bay of Biscay respectively. Body segments are identified by the vectors.

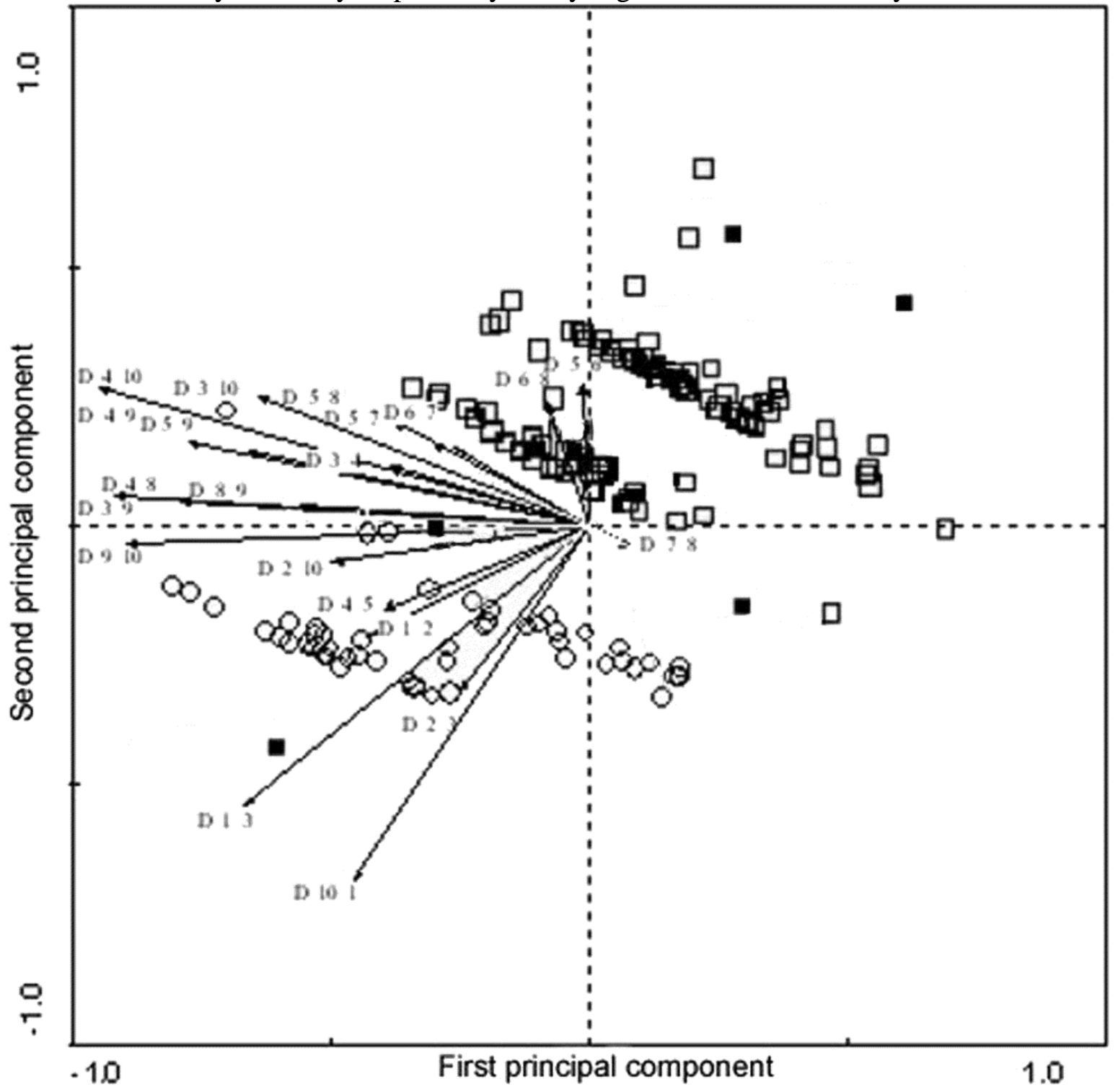


Figure 5: Averaged forms of M. surmuletus in the Bay of Biscay and in the Eastern English

488 Channel. Reconstructed forms are scaled in centimetres and represent body total length of 20 $\mathrm{cm}$.

\section{Bay of Biscay $\quad \mathrm{N}=57$}

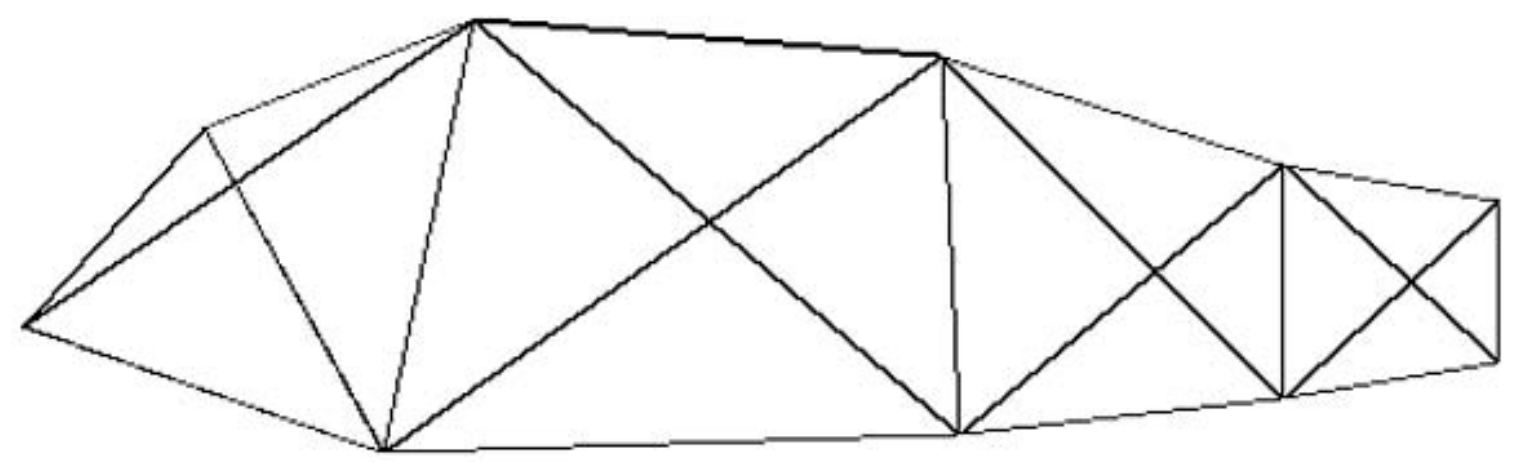

\section{Eastern English Channel $\quad \mathrm{N}=111$}

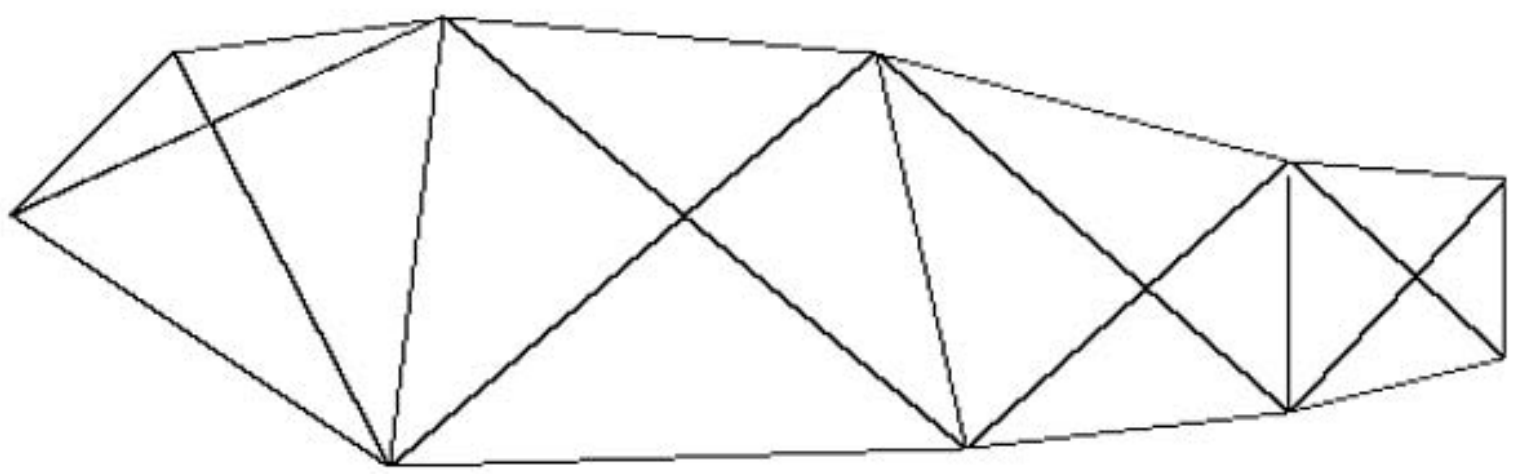

491 
497 Table I: Number, total length (mean+s.d.; mm) and total mass (mean+s.d.; g) of samples of 498 M. surmuletus used in groundfish surveys according to the stage of sexual maturity and sex. 499 CGFS: Channel Ground Fish Survey; EVHOE: Evaluation des ressources halieutiques de 500 l'ouest de l'Europe.

\begin{tabular}{|c|c|c|c|c|}
\hline Grou & indfish surveys & Juveniles & Females & Males \\
\hline \multirow{3}{*}{ CGFS 2002} & Number & 0 & 20 & 30 \\
\hline & mean total length (s.d.) & & $250(41)$ & $223(22)$ \\
\hline & mean total mass (s.d.) & & $236(140)$ & 145 (49) \\
\hline \multirow{3}{*}{ CGFS 2003} & Number & 16 & 28 & 17 \\
\hline & mean total length (s.d.) & $122(22)$ & $251(51)$ & $204(44)$ \\
\hline & mean total mass (s.d.) & $17(8)$ & $219(120)$ & $109(53)$ \\
\hline \multirow{3}{*}{\multicolumn{2}{|c|}{$\begin{array}{r}\text { Number } \\
\text { EVHOE } 2003 \text { mean total length (s.d.) } \\
\text { mean total mass (s.d.) }\end{array}$}} & 24 & 19 & 14 \\
\hline & & $120(13)$ & $214(51)$ & $241(50)$ \\
\hline & & $22(8)$ & $200(142)$ & $160(108)$ \\
\hline
\end{tabular}

501

502

503

504 